\title{
Correction to: The two-fold image and philosophy of personality in the works of F. M. Dostoevsky
}

\section{Tatiana Kasatkina ${ }^{1} \mathbb{D}$}

Published online: 9 September 2020

(c) Springer Nature B.V. 2020

\section{Correction to: Studies in East European Thought https://doi.org/10.1007/s11212-020-09374-2}

Above mentioned article was funded by a grant from the Russian Science Foundation (RSF). The correct grant number is Project No. 17-18-01432-П.

Publisher's Note Springer Nature remains neutral with regard to jurisdictional claims in published maps and institutional affiliations.

The original article can be found online at https://doi.org/10.1007/s11212-020-09374-2.

\section{Tatiana Kasatkina}

t-kasatkina@yandex.ru

1 Gorky Institute of World Literature RAS, Moscow, Russian Federation 